\title{
Citizen Participation in Health Budget Process: Trends and Patterns with Particular Reference to Enugu State of Nigeria
}

\author{
Simon Nnamdi Eneh \\ Ph.D. in Public Health, Texila American University, Nigeria
}

\begin{abstract}
This study looked at Citizen Participation in Health Budget Process: Trends and Patterns in Enugu state of Nigeria. The study's objectives included exploring citizens' perception of the factors that influence the release of funds in the State, their level of participation, and knowledge about the goals of citizen participation in the budget process. Respondents were 398 in number (198 males and 200 females), inclusive of 40 civil and public servants. The two sets of questionnaire were used to collect data (One set for the public and civil servants; and the other set for the general public. Results reveal that the factors that influence the release of funds include, among others, poor allocation and release of funds from federal sources and weak political commitment. The results also reveal that citizens are not openly and substantially involved in the health budget process, and their level of knowledge regarding the government's goal in citizen participation in the budget process is poor. The findings from this study will inform the development of advocacy packages to the government towards greater and meaning engagement of the citizens in the budget process. The advocacy packages might give the necessary voice to the people, which are required to strengthen efforts towards the attainment of Universal Health Coverage, as well as generate useful data which will serve as a guide for future interventions.
\end{abstract}

Keywords: Budgetary process, Citizen Participation, Health care financing, Health Sector Funding, Participatory budgeting, People-Task-Oriented Budgeting.

\section{Introduction}

The first wealth of any nation is the health of her populace. The health of a Nation is greatly determined by the belief that people have a right to influence public choices, especially relating to health issues that shape their lives. Health is financed by public and private funds, and how the budgets are formed, allocated, and used in the health sector is at the core of the Universal Health Coverage (UHC) agenda [1]. Bringing about changes in policy and budget allocations are often long-term objectives, and there will be many points during the budgetary process where one can make a change that will bring influence to bear and help re-shape the policy environment.
According to [2], public budgets are the instruments through which governments allocate the country's financial resources, including but not limited to financing health services. Even in the most open and democratic countries, a robust and transparent budget system can be difficult to achieve, calling attention to the fact that supporting governments to strive towards achieving an open budget and improving the budget system can be a good starting point for any country's health budget advocacy [2]. A good understanding of the budget process and solid engagement by the Ministry of Health and other health sector stakeholders at the right time during the budget cycle will increase the probability of a match between the ultimate 
resource allocation and the planned health sector needs. For instance, preparedness for health events/emergencies is like a protection policy for the health and prosperity of the populace of any State. Although it is hoped that a deadly epidemic does not occur, there is a need to ensure that every State of any country is always ready with budgetary provisions.

Budgets are the business of all citizens, including children and young people, as they are the rights-holders whose needs the government designs services to meet, budget advocacy can bring citizens closer to the decision-makers who affect their everyday lives, thus promoting transparency and accountability [2]. It's the duty of the government to provide for these rights, for which the citizens may hold their government accountable. The populace also has a right to influence government's decisions on how public resources are spent, both across and within sectors. Stakeholders at diverse levels are engaging more and more in analyzing and influencing government budgets on health, among other services, resulting in a greater say in government's decisions about spending priorities.

This study is formative research that explores the State's budgetary process (The trend and pattern) in the health sector. Specifically, the objectives were to:

1. Identify the factors that influence the release of funds in the State between 2011 and 2017.

2. Determine citizens' level of participation (Engagement, scope, and mechanisms) in the budget process of the health sector.

3. Ascertain the citizens' knowledge about the goals of citizen participation in the budget process.

The results are hoped to assist government and health administrators in health policy formulation, administration, and implementation for better service delivery. The study contributes to the development of the advocacy packages to the various key and relevant stakeholder groups at various levels of government. This package might give the necessary voice to the people, which are required to strengthen efforts towards the attainment of Universal Health Coverage, as well as generate useful data which will serve as a guide for future interventions. This study also provides a baseline reference source for many researchers and the needed data that may assist the Enugu State Government, health sectors, and other stakeholders in designing strategies and goals that will improve the Universal Health Coverage.

Literature on relevant and related articles shows that a budget is a financial plan prepared and used to estimate revenues to be generated and expenditures to be made in a specific period of time. It is a tool used not just as an accounting document but also supports and facilitates the allocation of funds as in planning and managing resources. According to [1], the health budget is the portion of the national budget allocated to the health sector, including all ministries and agencies involved in health-related activities. A health budget is more than a simple accounting instrument to present revenues and expenses rather, it is a crucial orienting text declaring the country's key financial objectives and its real commitment to implementing its health policies and strategies [1].

Fundamentally, developing strong health budget envelopes calls for strong and collaborative engagement with the relevant ministries, decision-makers, and their stakeholders, to make the health sector perspective clear, logical, and convincing. The way budgets are developed, allocated, and used in the health sector is crucial and at the centre of any health agenda, including the agendas for health emergencies. Ministries of Finance and related entities are the leading institutions for budget development, while Ministries of Health $(\mathrm{MOH})$ have the critical responsibility to prepare, present, negotiate and defend the credibility and priority-orientation of the 
proposed budget for the health sector. Relevant stakeholders (Civil society and the general public) can seek to contribute to health budget definition by engaging with the executive or the legislature. A sound understanding of the budget process and solid engagement of all relevant stakeholders at the right time during the budget process cycle by $\mathrm{MoH}$ will increase the likelihood that the final resource allocation matches planned health sector needs strategically. In the budgeting process, the allocation of resources to various institutions and for diverse purposes is basically a political rather than a purely bureaucratic process. As a result, after analyzing the needs and determining the most equitable and efficient policies and plans, stakeholders in health must be proactively engaged in this politically influenced process, as this engagement of relevant stakeholders determines the details and the relevance of the health budget, which impacts on effectiveness and efficiency of public spending for health.

In other words, how a budget is formulated and allocated to include the lower levels of government, such as the public, has a direct effect and impact on how effectively and efficiently funds can and will be used. Supporting a fair distribution of resources across populations and/or geographical areas is likely to have a direct impact on health sector outputs [3]. Where the health policy-making, planning, costing, and budgeting take place in parallel and independently of each relevant stakeholder group, it usually leads to a misalignment between the health sector priorities as stipulated in the overall strategic plans and policies, and the funds that are eventually allocated to the health sector through the budgeting process. This misalignment results in negative consequences as resources are not used as intended and planned, and accountability is lacking or weakened.

Citizen participation in budgetary processes is an arrangement that should be consciously put forward by an efficient and responsive government to actively and meaningfully engage citizens and have them make inputs into resource allocation decisions. Participatory budgeting is as a process that is open to any citizen who wants to participate and that combines direct and representative democracy, involving deliberation (not merely consultation), redistributes resources toward the poor, and is self-regulating, such that participants help define the rules governing the process, including the criteria by which resources are allocated [4]. Implicit in the definitions is the fact that in a participatory budgeting system, citizens have the right to say how part of the public resources should be spent [5]. It is not only about the decision itself but also a complex process including the identification of needs, formulation of needs, discussions, and prioritizing some of these needs [5]. The participatory budgeting programmes are implemented at the behest of governments, citizens, Non-Governmental Organizations (NGOs), and Civil Society Organizations (CSOs) to allow citizens to participate directly in deciding how and where resources should be spent [5]. According to [5], the practice of promoting deliberative democracy through citizen participation in budgetary decision making has been widespread for several decades now, buttressing that from an international perspective, the best-known form of citizen participation in budgeting is the Porto Alegre model, considered the initial attempt at participatory budgeting. In 1988, the progressive Workers' Party won the mayoral election in Porto Alegre, Brazil, explaining that in Porto Alegre, the government, together with civil society groups, experimented with a participatory budgeting program aiming to invert the budget's priorities by shifting resources from middle- and upper-class neighborhoods to lower-class ones [5], emphasizing that participatory budgeting has since spread to cities worldwide. 
Although participatory budgeting was developed and invented in Porto Alegre, the implementation of this system differed significantly in different countries [5]. It has been demonstrated that the models adopted by other countries in Europe for the implementation of participatory budgeting were unique to the conditions found in the area [6]. However, the core ingredient of participatory budgeting is participation, deliberation, empowerment and control, and monitoring, all of which should be decentralized. Participatory budgeting in developing countries should be advocated for by underlining its merits as promoting social justice and good governance and transparency by providing the government with information and facts that improve allocative or technical efficiency [7]. This is true as public inputs most times recommend innovative solutions that would not have been obvious from traditional modes of decision making. This study is based on a classic (People-Task-Oriented Budgeting) approach that considers the budget process as a system of interdependent actors (Citizens and government officials) behaving in a way to adequately response to control bottlenecks in their environment during the budget process. The formulated theoretical framework (PeopleTask-Oriented Budgeting Model) tries to explain the interconnectedness of actors in the budget process, proposing that when the external environment becomes more uncertain, the budget process requires increasing use of integrated mechanisms, such as budgetary participation to coordinate actions. The Figure below illustrates the relationship between the environment and the budget process as in the formulated People-Task-Oriented Budgeting Model for the study.

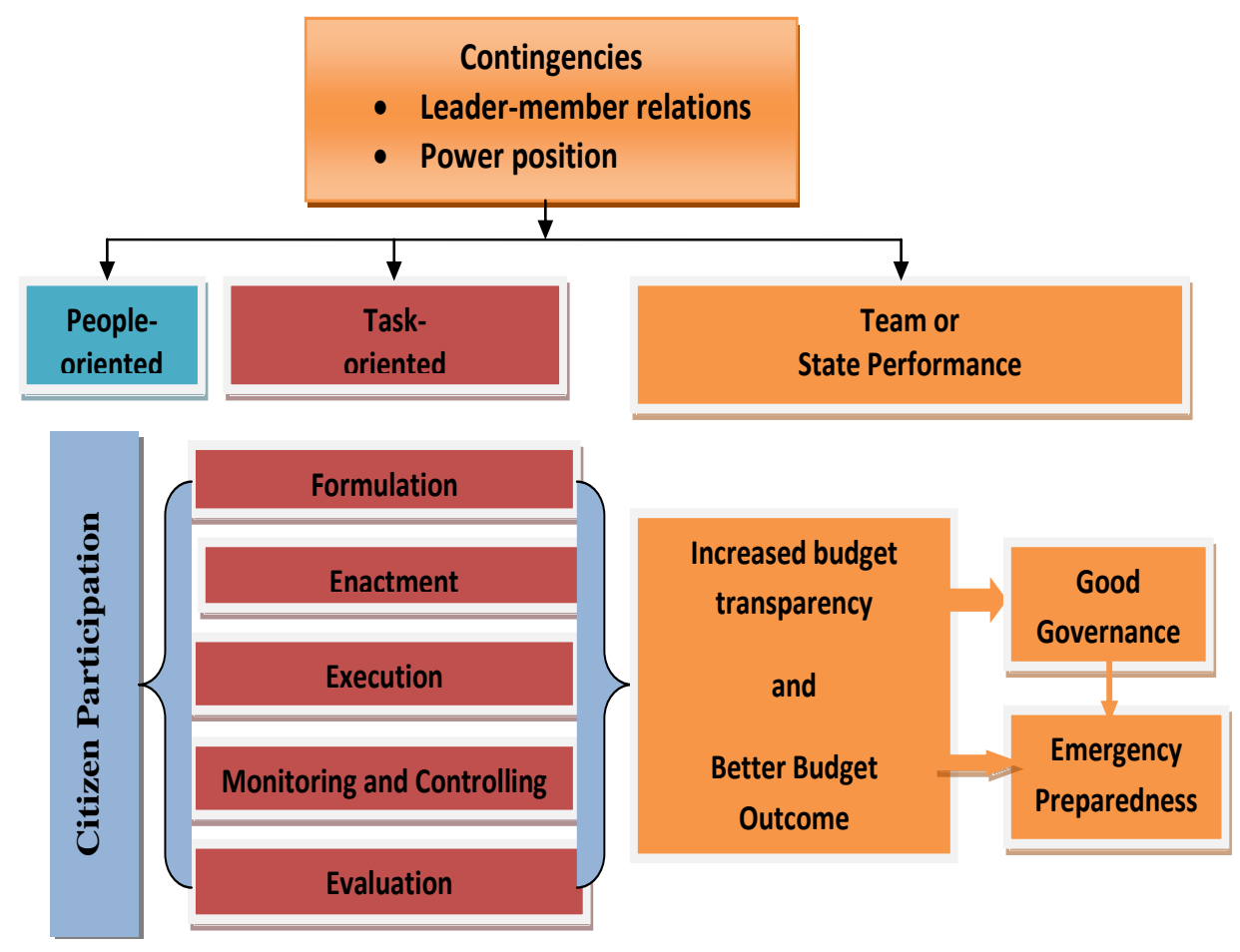

Figure 1. Formulated People-Task-Oriented Budgeting Model for the Study

This relationship postulates that the budget process being contingent on sound governmentpeople relations will bring about high performance. Participation in the budget process can guide citizens to convey their preferences at the various stages of the budget process to their governments, thus strengthening citizens' participation potential. This ensuing strength may, in turn, lead to a more responsive and effective government. Citizen participation is seen to have the likelihood to lead to better governance because 
a narrower distance between government and citizens can make public officials and government more accountable to citizens. The amount of information that is required for decision-making depends on the external environment, since as the environmental uncertainty increases, more relevant information for planning will be sought for [8]. Budgetary participation will provide more useful results when environmental uncertainty is high [8].

Through citizen engagement and participation in the budget process, it is envisaged that the distance between citizens and government officials becomes somewhat less significant. Such collaboration in the budget process gives interested citizens access to more and better information about governments and at the same time, gives the government deeper information about citizens' needs and preferences. Governments are more likely to have good budgetary outcomes if the citizens are involved at every of these three principles of the budget system: drafting (formulation), the legislative process (enactment), implementation (execution), along with auditing, execution (Implementation), monitoring and evaluation. Thus, it is very important that governments carry the public along and meaningfully engage them on the budget issues such as what taxes to levy, what services to provide, and how much debt to take on as these are crucial decisions that affect to a large extent the lives of the people.

The OBS is the world's only independent, comparative, and fact-based research instrument that uses internationally accepted criteria to assess public access to central government budget information; formal opportunities for the public to participate in the national budget process; and the role of budget oversight institutions such as the legislature and auditor in the budget process [9]. The 7th edition of the OBS was conducted in 117 countries of the world in 2019, of which Nigeria was one of them [9]. The survey looked at transparency, public participation, and budget oversight of the budget process. The transparency section of the OBS measures public access to information on how the central government raises and spends public resources, the online availability of the budget, timeliness, and comprehensiveness of eight key budget documents with 109 equally weighted indicators and a scale of 0 to 100 to score each country [9].

On transparency of the budget process, the Open Budget Survey (OBS) indicated that Nigeria has a transparency score of 21 (out of 100) compared to the other 116 countries, thus ranked: 97 out of 117 countries [9]. The global average is 45 [9].

Table 1. Transparency in Nigeria Compared to Others

\begin{tabular}{|l|l|}
\hline Global Average & 45 \\
\hline Ghana & 54 \\
\hline Sierra Leone & 39 \\
\hline Liberia & 38 \\
\hline Sao Tome e Principe & 24 \\
\hline Nigeria & 21 \\
\hline Equatorial Guinea & 5 \\
\hline Gambia & 4 \\
\hline Insufficient & 61 \\
\hline Sufficient & 100 \\
\hline
\end{tabular}

Source: International Budget Partnership, (2020), 2019 Open Budget Survey: Nigeria. p.2

Open Budget Survey (OBS) specified that a transparency score of 61 or above indicates a country is likely publishing enough material to support informed public debate on the budget. Open Budget Survey (OBS) went on to show how the transparency score for Nigeria has 
changed over time, with details of the public and the content over time [9] as follows: availability of the budget document to the

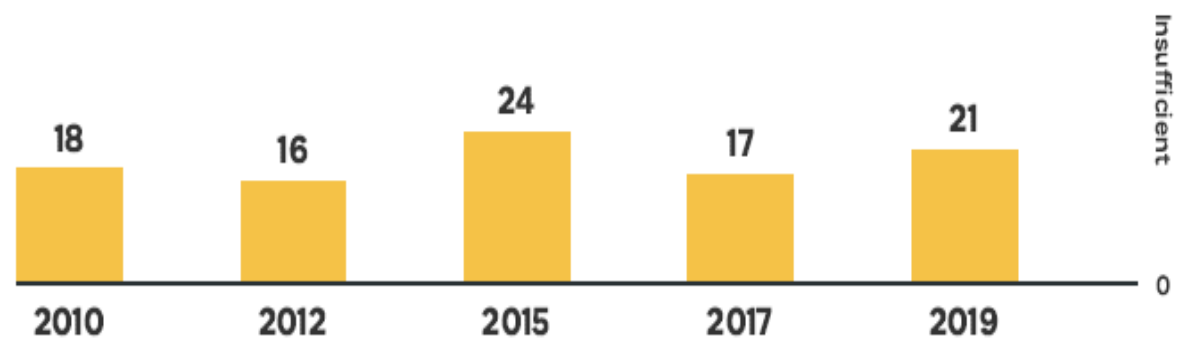

Figure 2. How has the Transparency Score for Nigeria Changed Over Time?

Source. International Budget Partnership, (2020), 2019 Open Budget Survey: Nigeria. p.3

It can be observed from the analysis that Nigeria's transparency score of 21 in the OBS 2019 is near the country's score of 17 in 2017 [9]. The reasons for the change range from the fact that Nigeria started publishing the Citizens Budget online and increased the information provided in the Enacted Budget, thus resulting in increased availability of budget information [9].

On public participation, it has been emphasized that transparency alone is not sufficient for improving governance, stating that inclusive public participation is crucial for realizing the positive outcomes associated with greater budget transparency and outcome [9]. The 2019 OBS also assessed the formal opportunities offered to the public for meaningful participation in the different stages of the budget process, examining the practices of the central government's executive, the legislature, and the supreme audit institution (SAI) using 18 equally weighted indicators [9]. The survey scored each country on a scale from 0 to 100 , with Nigeria having a public participation score of 22 (Out of 100) [9]. The global average is 14 [9].

Table 3. Public Participation in Nigeria Compared to Others

\begin{tabular}{|l|l|}
\hline Global Average & 14 \\
\hline Sierra Leone & 31 \\
\hline Nigeria & 22 \\
\hline Ghana & 15 \\
\hline Gambia & 9 \\
\hline Liberia & 6 \\
\hline Equatorial Guinea & 0 \\
\hline Sao Tome e Principe & 0 \\
\hline Insufficient & 61 \\
\hline Sufficient & 100 \\
\hline
\end{tabular}

Source: International Budget Partnership, (2020), 2019 Open Budget Survey: Nigeria. p.6 
On assessing opportunities for public participation in the budget process, the following scores regarding public involvement in budget formulation, approval, implementation, and audit were reported [9]. Nigeria scored 40 and below in all stages of public participation in the budget process as assessed by 2019 OBS [9].

\section{Legislative oversight}

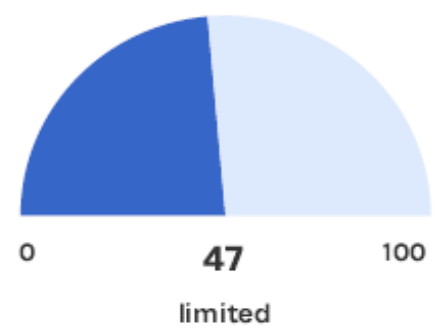

On oversight, Nigeria scored 47 (Limited) on legislative oversight and 72, which is adequate) on audit oversight processes as assessed by 2019 OBS [9], noting that the Implementation (executive) (supreme audit institution) Nigeria's Budget Office of the Federation has established public consultations during budget formulation and e-consultations during budget implementation.

\section{Audit oversight}

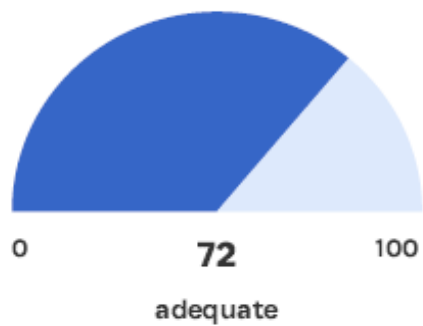

weak: 0 - 40; limited: 41 - 60; adequate: 61 - 100

Figure 4. Legislative and audit oversight

Source: International Budget Partnership, (2020), 2019 Open Budget Survey: Nigeria. p.6

However, the Nigeria's National Assembly provides limited oversight during the planning stage of the budget cycle and limited oversight during the implementation stage [9].

\section{Methods and Materials}

The two sets of questionnaire were used to collect data from the relevant authorities and representatives of citizens on their perception regarding the Enugu state budget allocations and performance and the citizen's involvement in the budget process. The survey was conducted in Enugu East Local Government Area (LGA) of Enugu State.

The study involved 400 persons (50\% males and $50 \%$ females) from age groups 20 to 69 years only. This is because these age groups can make decisions about their welfare and are likely to perceive better and deeper the challenges or otherwise in the budget process, especially as it concerns citizen engagement in the process. The inclusion criteria of respondents in the study were residence in Enugu for not less than 10 years; between 20 and 69 years of age, willingness to participate in the survey, and signing a consent form.

A three-stage multi-stage sampling technique was employed to select study villages, study households, and individual participants. In the first stage, the villages were the sampling units, and 17 out of 33 were selected, using the balloting method of the simple random sampling techniques. In the second stage, the selection of the compounds from the chosen villages using systematic sampling with a frame was done. At the third stage, the households became the sampling units, from which individuals that engaged in the study were picked through simple random sampling. Data collected were analyzed using frequency distribution tables and percentages. The necessary approvals, where applicable, were obtained. Furthermore, informed, and written consents were obtained from the participants. 


\section{Results}

Four hundred questionnaires were distributed. Out of this number, 398 participants (198males and 200 females) responded, giving a response rate of $99.5 \%$. Of the $99.5 \%, 198$ $(49.7 \%)$ were male and $200(50.3 \%)$ were females.

\section{Personal Characteristics of Respondents}

Table 4. Personal Characteristics of the Respondents

\begin{tabular}{|l|l|l|l|}
\hline \multirow{2}{*}{ Characteristics } & Male & Female & Total \\
\cline { 2 - 4 } & $\mathrm{n}=198(49.7 \%)$ & $\mathrm{n}=200(50.3 \%)$ & $\mathrm{n}=398$ \\
\hline Age of Respondents & $18(47.1 \%)$ & $21(52.9 \%)$ & $29(7.3 \%)$ \\
\hline $20-29$ yrs & $55(50.9 \%)$ & $53(49.1 \%)$ & $108(27.1 \%)$ \\
\hline $30-39$ yrs & $89(57.1 \%)$ & $67(42.9 \%)$ & $156(39.2 \%)$ \\
\hline $40-49$ yrs & $22(27.5 \%)$ & $58(72.5 \%)$ & $80(20.1 \%)$ \\
\hline $50-59$ yrs & $14(56.0 \%)$ & $11(44.0 \%)$ & $25(6.3 \%)$ \\
\hline $60-69$ yrs & \multicolumn{4}{|l}{} \\
\hline Educational attainment & $5(38.5 \%)$ & $13(3.2 \%)$ \\
\hline No education & $8(61.5 \%)$ & $18(38.3 \%)$ & $47(11.8 \%)$ \\
\hline Primary education & $29(61.7 \%)$ & $76(56.7 \%)$ & $134(33.7 \%)$ \\
\hline Secondary education & $58(43.3 \%)$ & $101(49.5 \%)$ & $204(51.3 \%)$ \\
\hline Tertiary education & $103(50.5 \%)$ & \multicolumn{3}{|l}{} \\
\hline Residence & $169(58.7 \%)$ & $119(41.3 \%)$ & $288(72.4 \%)$ \\
\hline Urban & $16(40.0 \%)$ & $24(60.0 \%)$ & $40(10.0 \%)$ \\
\hline Rural & $43(61.4 \%)$ & $27(38.6 \%)$ & $70(17.6 \%)$ \\
\hline Semi-urban
\end{tabular}

Female respondents were slightly greater (200 [50.3\%]) in number than males (198 [49.7\%]). The findings revealed that most of the respondents were in the age range of $40-49$ years $(39.2 \%)$, followed closely by the age range 30 - 39 year $(27.1 \%)$. Educational attainment majority of the respondents had secondary level education and above $33.7 \%$ and $51.3 \%$ ), respectively. Primary education attainment showed $11.8 \%$ of respondents, while no education had the least $(3.2 \%)$. Most respondents $(72.4 \%)$ were urban residents as at the time of the study, followed by the semiurban resident (17.6\%), respondents residing in the rural areas were least (10\%).

\section{Factors that Influence the Release of Funds in the State}

On the factors that influence the release of funds, the respondents indicated that some of the factors that influence allocation and release are as in the Table below:

Table 5. Factors that Influence Allocation and Release $(n=398)$

\begin{tabular}{|l|l|}
\hline Factors & \% Response \\
\hline Poor allocation/release of funds from federal sources & 60 \\
\hline Low IGR to supplement federal funding & 36 \\
\hline Competing demands of another sector & 38 \\
\hline Bureaucratic financial management processes & 58 \\
\hline Weak political commitment to achieve policy objectives & 52 \\
\hline Pressure from donors and development partners in the state & 52 \\
\hline
\end{tabular}


International declarations led by institutions such as United African Union 27

and Federal reforms agreed at the National Council of Health, among others.

Most (60\%) stakeholders interviewed agreed that the major health financing challenge in Enugu state is poor allocation and release of funds from the federal government. This view was followed by weak political commitment and pressure from donors and development partners in the State $(52 \%$ and $53 \%)$, respectively).

\section{Citizens' Level of Participation (Engagement, Scope, and Mechanisms) in the Health Budget Process} engagement in the budget process, the scope of engagement, and the mechanisms for the engagement.

\section{Engagement of Citizens in the Budgetary Process}

Responses to the government's invitation of inputs from citizens in the budgetary process revealed that $338(85 \%)$ respondents disagreed, $44(11 \%)$ respondents agreed, with $16(4 \%)$ being undecided, as illustrated in Table 6 .

Responses to this objective revealed
different levels of opinion regarding

Table 6. Engagement of Citizens in the Budgetary Process $(\mathrm{n}=398)$

\begin{tabular}{|c|c|c|c|c|c|}
\hline Study Statement & Strongly agree & Agree & Undecided & Disagree & Strongly disagree \\
\hline \multirow{2}{*}{$\begin{array}{l}\text { Enugu state government } \\
\text { invites inputs of citizens } \\
\text { into the budget }\end{array}$} & 12 & 32 & 16 & 330 & 8 \\
\hline & $(3 \%)$ & $(8 \%)$ & $(4 \%)$ & $(83 \%)$ & $(2 \%)$ \\
\hline \multirow{2}{*}{$\begin{array}{l}\text { Timing of the input of the } \\
\text { citizens is given a priority } \\
\text { in the budgetary process. }\end{array}$} & & & & 354 & 44 \\
\hline & 0 & 0 & 0 & $(89 \%)$ & $(11 \%)$ \\
\hline \multirow{2}{*}{$\begin{array}{l}\text { The invitation for } \\
\text { participation comes early } \\
\text { in the budgetary process }\end{array}$} & 8 & 12 & & 366 & 12 \\
\hline & $(2 \%)$ & $(3 \%)$ & 0 & $(92 \%)$ & $(3 \%)$ \\
\hline \multirow{2}{*}{$\begin{array}{l}\text { The invitation for } \\
\text { participation comes at any } \\
\text { time during the budgetary } \\
\text { process }\end{array}$} & 334 & 16 & 40 & 8 & \\
\hline & $(84 \%)$ & $(4 \%)$ & $(10 \%)$ & $(2 \%)$ & 0 \\
\hline \multirow{2}{*}{$\begin{array}{l}\text { Citizen participation is } \\
\text { used more frequently at the } \\
\text { end of the process }\end{array}$} & 28 & 24 & 16 & 322 & 8 \\
\hline & $(7 \%)$ & $(6 \%)$ & $(4 \%)$ & $(81 \%)$ & $(2 \%)$ \\
\hline
\end{tabular}

Similarly, regarding whether the timing of inputs of the citizens is given a priority, all 398 $(100 \%)$ respondents disagreed, with 354 respondents (89\%) just disagreeing and 44 respondents $(11 \%)$ strongly disagreeing. This issue was cross-examined with whether the invitation for participation comes early in the budgetary process. The response to this also showed that out of the 398 responses, 378 (95\%) respondents disagreed (92\% disagreeing and 3\% strongly disagreeing). Correspondingly, the majority of them, 350 (88\%), agreed that the invitation for participation comes at any time during the budgetary process.

It is worthy of note that of the 398 respondents, 330 (83\%) disagreed with the statement that citizens' participation is used more frequently at the end of the budget process. From the above findings, it can be deduced that citizens, to a great extent, are not engaged in the budget process. 


\section{Scope of Engagement of the Citizens}

On the scope of engagement with the citizens, the majority of the respondents, 338 (85\%), disagreed with all statements regarding input being more beneficial during the preparation stage rather than the budgetadoption phase, the existence of instances of budget input occurring early in the process, participation being open to large numbers of people, and representative of the community. However, 60 (15\%) respondents remained undecided on all statements, as in the chart below.

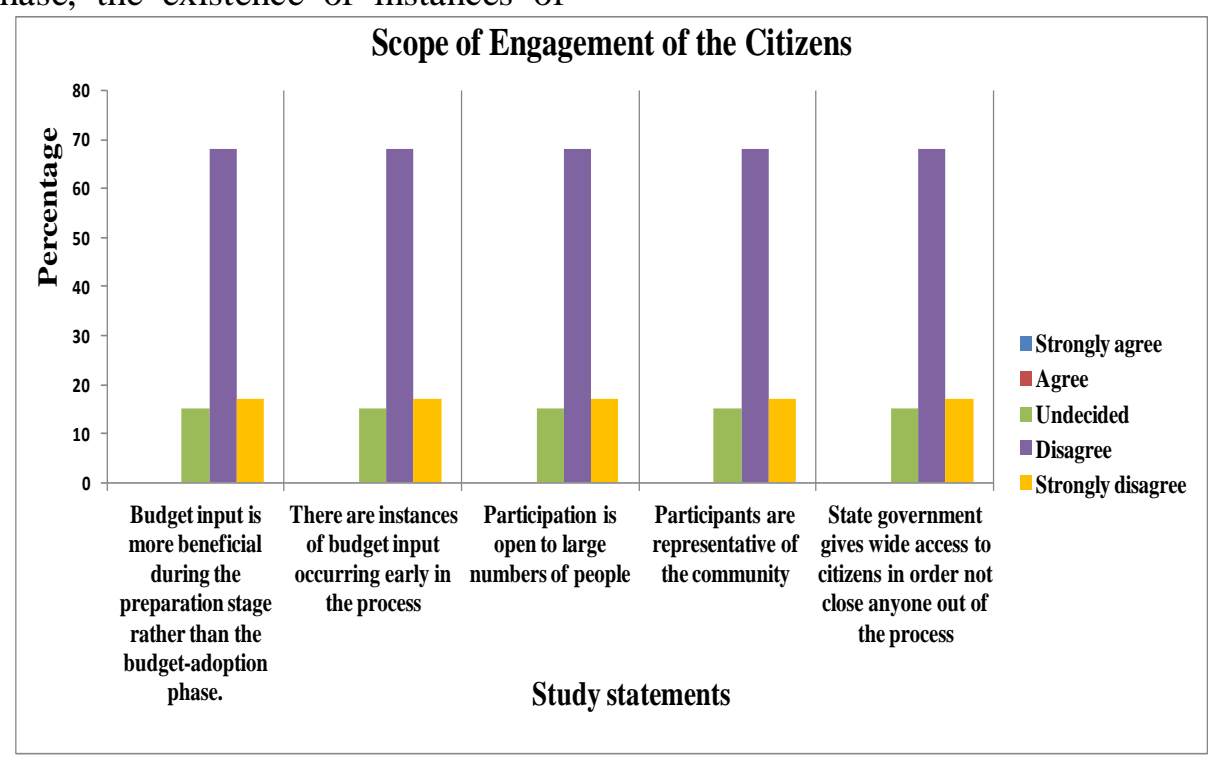

Figure 5. Scope of Engagement of the Citizens $(n=398)$

\section{Mechanisms used to Engage Citizens in the Budget Process}

On the mechanism of engagement, out of 398 respondents, 338 (85\%) disagreed with all the statements about the use of public meetings, focus group discussions, citizens surveys, or town meetings to elicit citizen participation in the budget process. Noteworthy is the opinion regarding the use of budget committees, where 107 (27\%) respondents agreed with the statement, while 263 (66\%) respondents disagreed.

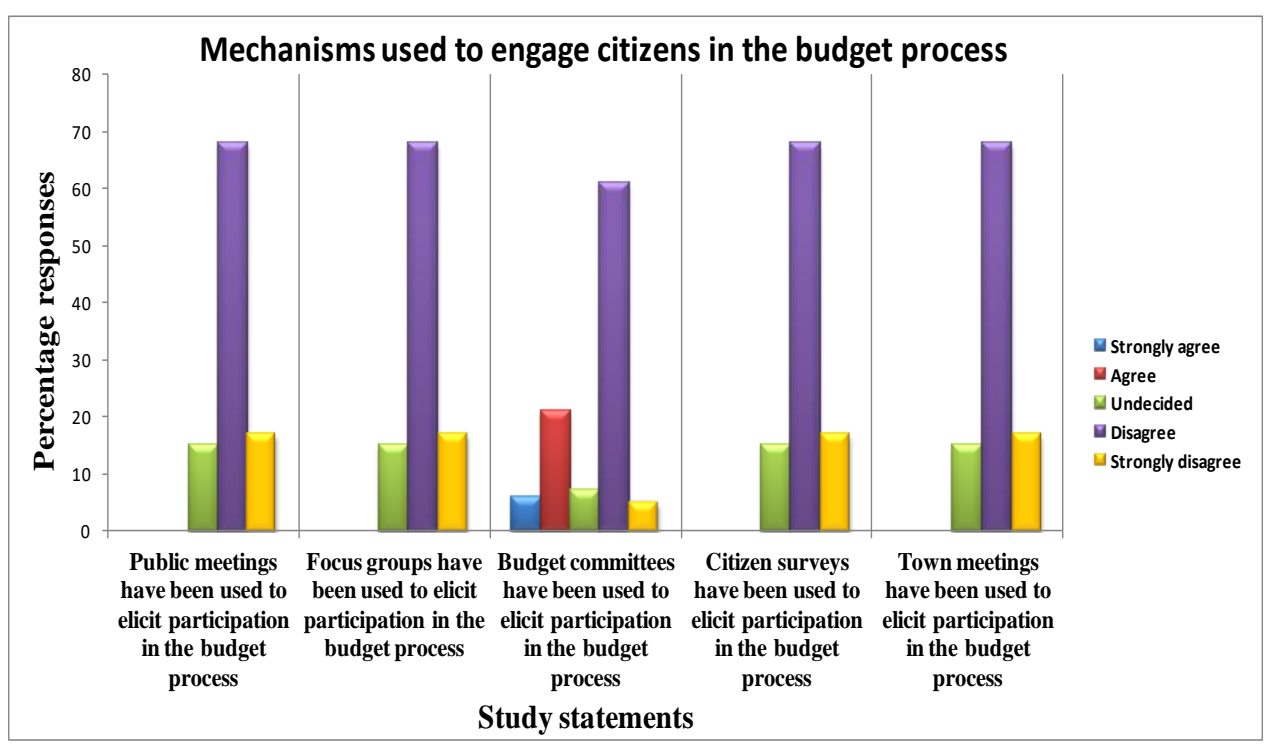

Figure 8. Mechanisms used to Engage Citizens in the Budget Process $(n=398)$ 
It can be seen from the responses above that the perception of the citizens regarding mechanisms and scope of engagement of citizens in the budget process are similar, except for the use of budget committees where 107 (27\%) agreed, and 28 (7\%) remained undecided.

\section{Citizens' Knowledge about the Goals of Citizen Participation in Budget Process}

The governments' goal of citizens' citizens. Responses to whether the goal is informing decision making revealed that the majority (227 [57\%]) of the respondents disagreed, with 139 (35\%) being undecided, leaving only $32(8 \%)$ respondents with the agreement. To whether the government goal is educating citizens on the budget, 200 (50\%) respondents disagreed, 80 (20\%) respondents were undecided, while 118 (30\%) respondents agreed. participation is not clearly understood by the

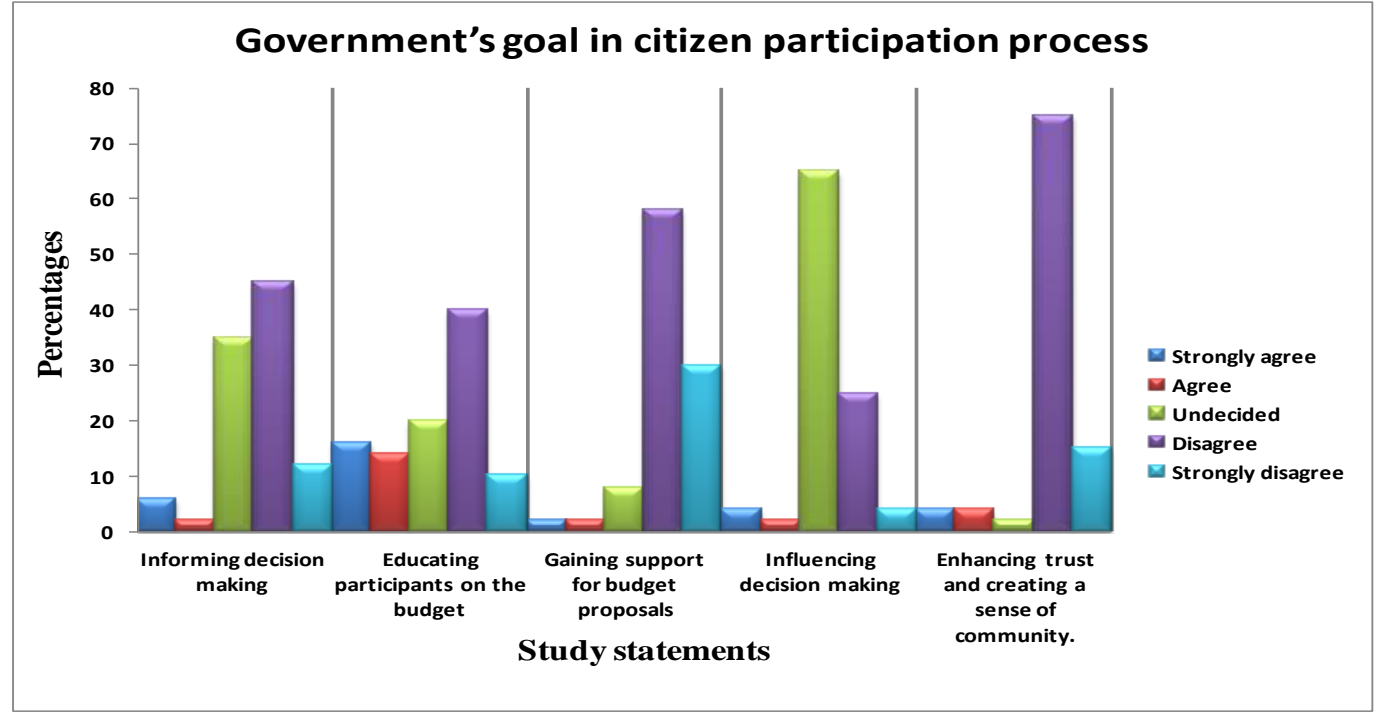

Figure 7. Government's Goal in Citizen Participation Process $(\mathrm{n}=398)$

Responses to whether the goal is to gain support for the budget process stood out, with the majority (350 [88\%]) of the respondents disagreeing; $32 \quad(8 \%)$ respondents were undecided, and 16 (4\%) agreed. On influencing decision-making as the goal of government, the majority (259 [65\%]) of the respondents were undecided. This was followed by those that disagreed 115 (29\%), with the respondents that agreed coming at least $24(6 \%)$. To the issue of enhancing trust and creating a sense of community as a goal of government for citizens' participation, about 358 (90\%) respondents disagreed, while $32(8 \%)$ were in agreement and only 8 (2\%) remained undecided. The responses are as displayed in the chart below.

It can be deduced that the respondents disagreed with all the statements regarding what the goal of the government is, except for influencing decisions where the majority remained undecided, which might imply a disagreement too since the respondent expressed a negative opinion to the other statements.

There was observed gaps in the level of knowledge among participants regarding citizen participation in the budget process. It is also noted that there is a limited number of studies on citizens' participation at the State and local government levels.

\section{Discussion}

\section{Factors that Influence the Release of Funds in the State}

All respondents agreed that the major health financing challenge in Enugu state is poor allocation and release of funds. Although some 
of the budgeted funds are contributions from donors on programs, those funds expected from partners have not yet been added to the funds utilized in the health sector. Furthermore, the budget release was indicated by respondents to be very low and due to delays from the federal government sources.

Fundamentally, developing strong health budget envelopes calls for strong and collaborative commitment from the government at all levels through engagement with the relevant ministries, decision-makers, and their stakeholders.

In the budgeting process, the allocation of resources to various institutions and for diverse purposes is basically a political rather than a purely bureaucratic process. How the budgets are formed, allocated, and used in the health sector is at the core of the Universal Health Coverage (UHC) agenda [1]. Similarly, supporting a fair distribution of resources across populations and/or geographical areas is likely to have a direct impact on health sector outputs [3].

\section{Citizens' Level of Participation (Engagement, Scope, and Mechanisms) in the Health Budget Process}

The findings showed that citizens do not participate at any stage in the budget process. This does not differ from the reports of the Open Budget Survey (OBS) conducted in on transparency of the budget process. Nigeria has a transparency score of 21 (out of 100) compared to the other 116 countries, thus ranking 97 out of 117 countries [9], and the global average reported as 45 . It can be observed from the analysis that Nigeria's transparency score of 21 in the OBS 2019 is near the country's score of 17 in 2017 [9], stating that the reasons for the change range from the fact that Nigeria started publishing the Citizens Budget online and increased the information provided in the Enacted Budget, thus resulting in increased availability of budget information.
On public participation, transparency alone is not sufficient for improving governance, and inclusive public participation is crucial for realizing the positive outcomes associated with greater budget transparency and outcome [9]. The 2019 OBS also surveyed the formal opportunities offered to the public for meaningful participation in the different stages of the budget process, scoring each country on a scale from 0 to 100 , with Nigeria having a public participation score of 22 (Out of 100), [9] and the global average was reported as 14.

On oversight, Nigeria scored 47 (Limited) on legislative oversight and 72 (which is adequate) on audit oversight processes as assessed by 2019 OBS [9]. The Implementation (executive) Nigeria's Budget Office of the Federation has established public consultations during budget formulation and e-consultations during budget implementation. However, Nigeria's National Assembly provides limited oversight during the planning stage of the budget cycle and limited oversight during the implementation stage [9].

International Budget Partnership (2020) emphasized that though Nigeria's Budget Office of the Federation has established public consultations during budget formulation and econsultations during budget implementation but, to further strengthen public participation in the budget process [9], there is need also prioritize the expansion of mechanisms during budget formulation through implementation to monitoring, that engages any civil society organization or member of the public who wishes to participate.

The Nigerian government should actively engage with vulnerable and underrepresented communities, directly or through civil society organizations representing them; and Nigeria's Office of the Auditor-General for the Federation should prioritize the establishment of formal mechanisms for the public to assist in developing its audit program and to contribute to relevant audit investigations [9]. 


\section{Citizens' Knowledge about the Goals of Citizen Participation in Budget Process}

Respondents indicated little or no knowledge of the goals of government in the budget process. This might be from the absence of engagement or a low level of engagement. For participatory budgeting in developing countries, it is important to focus by underlining its merits as promoting social justice and good governance and transparency by providing the government with information and facts that improve allocative or technical efficiency. This is true as public inputs most times recommend innovative solutions that would not have been obvious from traditional modes of decision making.

\section{Conclusion}

Improved budget outcome and thus good governance requires the greater and meaningful engagement of the citizens the unity between (those who have the information) and the government (Those who need the information). To move towards achieving continuous improvement in budget outcomes, the government should develop strategies for citizens' interaction and participation through all stages of the budget process.

This translates into a redefinition of the budget process, and mechanisms to better meet citizens' expectations and schedules. Engaging large and varied groups/bodies that are

\section{References}

[1] Rajan, D., Barroy, H, and Stenberg K., (2016). Budgeting for health. In: Schmets G, Rajan D, Kadandale S, editors. Strategizing national health in the 21st century: a handbook. Chapter 8. Geneva: World Health Organization. http://apps.who.int/iris/bitstream/handle/10665/2502 21/9789241549745-chapter8eng.pdf?sequence $=11 \&$ is Allowed $=y$.

[2] Save the Children, (2012). Health Sector Budget Advocacy: A guide for civil society organisations. representatives of others in all phases of budgeting would be the star strategies that will ultimately give a fair picture of concrete citizens' agendas. When the participation involves only one stakeholder group, it might imply that it is only the voice of a particular section of the community or special group that is being heard, which might lead to achieve the goal of widespread representation and engagement.

In other words, participation in the budget process should entail efforts to bring all relevant stakeholders together through the institutionalization of appropriate structures, scope, and mechanisms to actively and meaningfully engage relevant citizens' groups towards a well-defined and prioritized goal in all the phases of the budget process.

\section{Conflict of Interest}

No conflict of interest in this study.

\section{Acknowledgement}

I wish to express my profound gratitude to the numerous individuals and institutions (State Ministries of Health and Finance) that supported me during the course of this survey. Their immense knowledge, profound experience, and expertise in data harvest, collection, and collation have helped me to complete this study successfully. It would have been a much more daunting task without their support.

https://www.who.int/pmnch/media/news/2012/2012 05_health_sector_budget_advocacy.pdf.

[3] Cashin, C., (2016). Health financing policy: the macroeconomic, fiscal, and public finance context. Washington (DC): World Bank Group. http://documents.worldbank.org/curated/en/3940314 67990348481/Health-financing-policy-themacroeconomic-fiscal-and-public-finance-context. [4] Iloh C. E. \& Nwokedi M. E., (2016). Budget Processes and Participatory Budgeting in Nigeria: Lessons from Latin America. ANSU Journal of Arts and Social Sciences, 5(1): 135-154. https://oidp- 
afrique.org/wp-content/uploads/2020/04/NigeriaBudget_Processes_and_Participatory_Budge.pdf. [5] Bisong, Daniel Bisong and Ogwumike, Jam Hill Chiddy, (2020). Citizen Participation in Budgetary Processes and Effective Governance in Nigeria Journal of Public Administration and Social Welfare Research: 5(2) 2020 ISSN E-ISSN 2504-3597 PISSN 2695-2440.

https://iiardpub.org/get/JPASWR/VOL. $\% 205 \% 20 \mathrm{~N}$

O.\%202\%202020/Citizen\%20Participation\%20in\%2 0Budgetary.pdf.

[6] Klimovsky, D., (2017). Participatory Budgeting in Slovakia: Experience from Bratislava and Ružomberok in Participatory Budgeting Klimovsky D.(ed). Project "Capacity Building of NAPA for Open Local Governance".
[7] Shah, Anwar, (2007). Participatory Budgeting: Public Sector Governance and Accountability. Washington, DC: World Bank. https://openknowledge.worldbank.org/handle/10986/ 6640.

[8] Anissa, D. B. and Habib, A., (2021). Corporate Budget Governance Through the Operating Managers Commitment: What is the problem? https://www.pubtexto.com/journals/journal-ofeconomic-and-business-studies/fulltext/corporatebudget-governance-through-the-operatingmanagers-commitment-what-is-the-problem. [9] International Budget Partnership, (2020). 2019 Open Budget Survey: Nigeria. https://www.internationalbudget.org/open-budgetsurvey/country-results/2019/nigeria. 